\title{
In Vitro Activity of Synthesized 6-Chloro-2-methyl-1 $H$-carbazole- 1, 4(9H)-dione against Methicillin-Resistant Staphylococcus aureus
}

\author{
Biswanath Chakraborty ${ }^{1}$, Suchandra Chakraborty ${ }^{2}$, Indrani Bhattacharyya ${ }^{3}$, \\ Chandan $\mathrm{Saha}^{2}$ \\ ${ }^{I}$ Department of Biochemistry \& Medical Biotechnology, School of Tropical Medicine, Kolkata - 700073, India. \\ ${ }^{2}$ Department of Clinical \& Experimental Pharmacology; School of Tropical Medicine, Kolkata - 700073.India. \\ ${ }^{3}$ Department of Microbiology, School of Tropical Medicine, Kolkata - 700073.India.
}

\begin{abstract}
The antimicrobial activity of synthesized 6-chloro-2-methyl-1H-carbazole-1,4(9H)-dione and 6chloro-3-methyl-1H-carbazole-1,4(9H)-dione were studied against Escherichia coli (MTCC 42), Bacillus subtilis (MTCC 121), Staphylococcus aureus (MTCC 96), methicillin-resistant Staphylococcus aureus (MRSA) and Pseudomonas sp.(MTCC 6199). 6-Chloro-2-methyl-1H-carbazole-1,4(9H)-dione having methyl substituent at $C-2$ and electron withdrawing chloro group at C-6 exhibited the remarkable antibacterial activity against methicillin-resistant Staphylococcus aureus (MRSA) with MIC value of $50 \mu \mathrm{g} / \mathrm{mL}$ and against Staphylococcus aureus (MTCC 96) with MIC value of $100 \mu \mathrm{g} / \mathrm{mL}$. However, 6-chloro-3-methyl-1H-carbazole-1,4(9H)-dione bearing methyl substituent at $C-3$ with chloro group at $C-6$ does not exhibited any antimicrobial activity against these pathogenic bacteria.
\end{abstract}

Keywords: Anti-MRSA activity, Carbazoloquinone, MIC, Structure-activity relationship.

\section{Introduction}

Widespread use and misuse of antibiotics have caused the emergence of drug resistant bacteria, which is a serious threat to public health. In addition, the emergence of multidrug resistant gram-positive bacteria, including methicillin-resistant Staphylococcus aureus (MRSA), is a serious concern for microbiologists. Therefore, recent efforts have been intended for exploring novel antibacterial agents to deal with resistant bacteria.

After the isolation of Murrayanine (3-formyl-1-methoxycarbazole), a carbazole alkaloid having promising antibiotic properties, from Murraya koenigii Spreng by Chakraborty et al. $(\mathbf{1 , 2 , 3 )}$, researchers tried to explore the chemistry and biological properties of carbazole derivatives (4-7). The enormous escalation of carbazole chemistry have got novel panorama after the isolation of carbazomycins. Carbazomycin alkaloids 1-8 were first isolated by Nakamura et al. from Streptoverticillium ehimense H 1051-MY10 (8-14) as shown in Fig. 1. Knölker et.al. have also been synthesized Carbazomycin A, B, C and D (15-18).<smiles>[R9]c1c(OC)c(C)c(C)c2[nH]c3ccccc3c12</smiles>

1 Carbazomycin $\mathrm{A}\left(\mathrm{R}=\mathrm{CH}_{3}\right)$ 2 Carbazomycin $B(R=H)$<smiles>[R]Oc1c(OC)c(C)c(C)c2[nH]c3ccc(OC)cc3c12</smiles>

5 Carbazomycin $\mathrm{C}(\mathrm{R}=\mathrm{H})$ 6 Carbazomycin $\mathrm{D}\left(\mathrm{R}=\mathrm{CH}_{3}\right)$<smiles>[R]c1ccc2[nH]c3c(C=O)c(C)c(OC)c(O)c3c2c1</smiles>

3 Carbazomycin $\mathrm{E}(\mathrm{R}=\mathrm{H})$ 4 Carbazomycin $\mathrm{F}\left(\mathrm{R}=\mathrm{OCH}_{3}\right)$

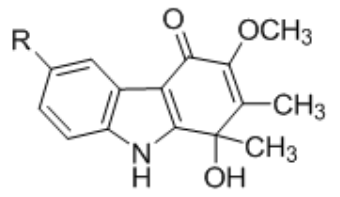

7 Carbazomycin $\mathrm{G}(\mathrm{R}=\mathrm{H})$ 8 Carbazomycin $\mathrm{H}\left(\mathrm{R}=\mathrm{OCH}_{3}\right)$

Fig. 1: Carbazomycin alkaloids 
It has been observed that carbazole ring is present in a variety of naturally occurring medicinally active substances. Though Carbazomycin B was found to be most potent among the carbazomycins, both Carbazomycin A [1] and Carbazomycin B [2] inhibit the growth of phytopathogenic fungi and exhibit antibacterial and antiyeast activities (8). Inhibitory activity of Carbazomycin B [2] and Carbazomycin C [3] against 5-lipoxygenase were also observed (19). Carbazomycin G [7], having unique quinol moiety, shows antifungal activity against Trichophyton species (14). Recently we have reported that 3-methyl- $1 H$-carbazole1,4(9H)-dione and 6-methoxy-3,7- dimethyl-2,3-dihydro- $1 H$-carbazole-1,4(9H)-dione both having unique quinone moiety, exhibited antibacterial activity (20).

Close scrutiny of various carbazole derivatives and their effective anti-microbial activity help us to understand that the structurally rigid carbazole nucleus having extensive $\pi$-conjugated system (21) with desirable electronic charge transfer properties along with the presence of indole moiety exhibit diverse biological activities such as antibacterial (22,23), antifungal (24,25), antiviral (26), anticancer (27) and various other activities. Besides the general biological activity, carbazole-1,4-quinones have highest anti-TB activity $(28,29)$.

It has also been reported that selective bioactivity is highly responsible due to the positioning of functional groups like $-\mathrm{H},-\mathrm{OH}$ and $-\mathrm{CH}_{3}$ (30). Structure elucidation of Carbazomycin $\mathrm{G}$ and $\mathrm{H}$ revealed that both have methyl substitution at $\mathrm{C}$-2. In addition, it is worth mentioning that several 3-methylcarbazole alkaloids $(\mathbf{3 1}, \mathbf{3 2})$ have also been isolated from higher plants and the oxidative functional variants of 3-methyl group such as $\mathrm{CH}_{2} \mathrm{OH}, \mathrm{CHO}, \mathrm{COOH}$ and $\mathrm{COOCH}_{3}$ have been encountered in various alkaloids. Again it has been noticed that the presence of any electron withdrawing group, especially chloro group, in the aromatic ring of the carbazolo-quinones enhances the polarity, solubility as well as stability of the nucleus.

Exploring this concept of functional group assisted reactivity, oxidizing property of the quinone moiety and polarity of the chloro group, we have synthesized two regioisomers: 6-chloro-2-methyl- $1 \mathrm{H}$ carbazole-1,4(9H)-dione [9] and 6-chloro-3-methyl-1H-carbazole-1,4(9H)-dione [10] possessing methyl group at 2 and 3 position respectively (Fig. 2).<smiles>CC1=CC(=O)c2c([nH]c3ccc(Cl)cc23)C1=O</smiles>

6-chloro-2-methyl-1H-carbazole-1,4(9H)-dione<smiles>CC1=CC(=O)c2[nH]c3ccc(Cl)cc3c2C1=O</smiles>

6-chloro-3-methyl-1 $H$-carbazole-1,4(9H)-dione

Fig. 2: Structure of compound 9 and 10.

These regioisomers having carbazoloquinone moiety were then evaluated for their antimicrobial activity against Escherichia coli (MTCC 42), Pseudomonas sp. (MTCC 6199), Bacillus subtilis (MTCC 121), Staphylococcus aureus (MTCC 96) and methicillin-resistant S. aureus (MRSA).

\section{Materials and Methods}

1.1 Materials: All starting chemical compounds were obtained from Aldrich. Nutrient broth, agar powder and antibiotic disks were purchased from Himedia. Dimethylsulphoxide (DMSO) was purchased from E. Merck. Compound $\mathbf{9}$ and compound $\mathbf{1 0}$ used in this work were synthesized in our laboratory.

1.2 Synthesis of compound 9 and compound10: A solution of methyl substituted cyclohexanones [11] in dry ether was treated with ethyl formate along with metallic sodium in presence of one drop of ethanol to furnish formyl derivatives 12 via Claisen condensation (33). Subsequent condensation of 12 with suitable phenyldiazonium chloride [13] yielded corresponding methyl-phenylhydrazono-cyclohexanone derivatives [14] under Japp-Klingemann condition (34). Further acid catalysed Fischer Indole Cyclisation (34) of 14 in concentrated hydrochloric acid and glacial acetic acid yielded corresponding ketotetrahydrocarbazole [15]. Ultimately, the desired carbazoloquinones 9 and $\mathbf{1 0}$ were obtained by $\mathrm{CAN}-\mathrm{SiO}_{2}$ mediated oxidation (35) of $\mathbf{1 5}$ at room temperature (Scheme 1). 

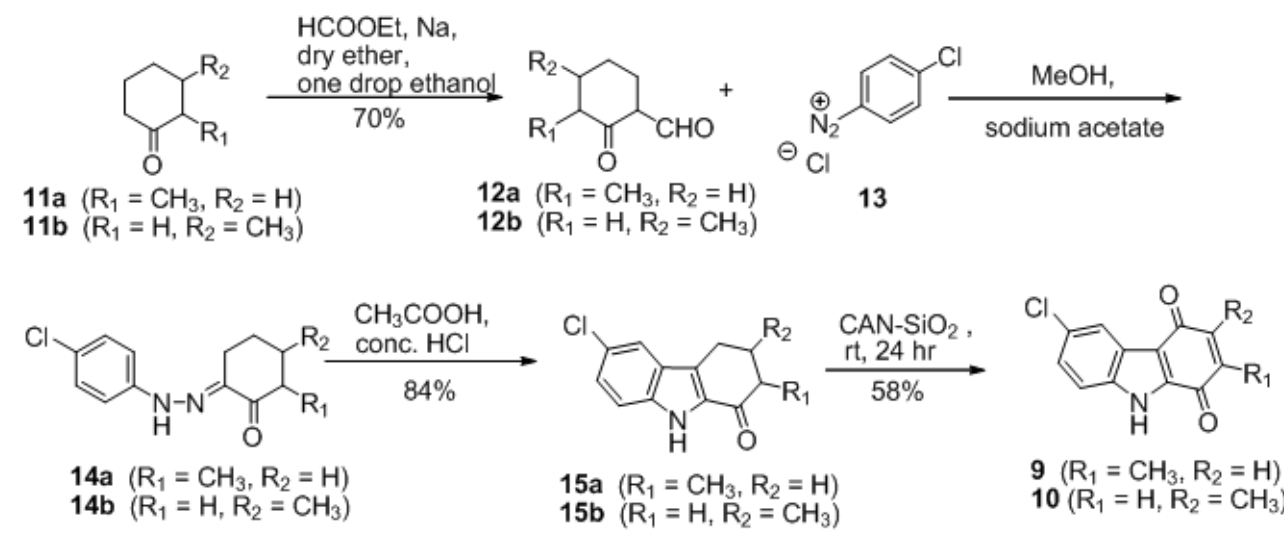

$9\left(\mathrm{R}_{1}=\mathrm{CH}_{3}, \mathrm{R}_{2}=\mathrm{H}\right)$

Scheme 1: Synthesis of compound 9 1nd 10.

2-Methyl-6-chloro-1H-carbazole-1,4(9H)-dione [9]. m.p. $260^{\circ} \mathrm{C}$ (dec.); UV (MeOH) : 227, 259, 322, 380; IR $(\mathrm{KBr}): \mathrm{v}=3207,2977,1665,1635 \mathrm{~cm}^{-1} ;{ }^{1} \mathrm{H}$ NMR (DMSO-d 6 , 500MHz): $2.04\left(\mathrm{~s}, 3 \mathrm{H}, \mathrm{C}_{2}-\mathrm{CH}_{3}\right), 6.56(\mathrm{~s}, 1 \mathrm{H}$, $\left.\mathrm{C}_{3}-\mathrm{H}\right), 7.44-7.57\left(\mathrm{~m}, 1 \mathrm{Hx} 2, \mathrm{C}_{7}-\mathrm{H} \& \mathrm{C}_{8}-\mathrm{H}\right), 8.21\left(\mathrm{~s}, 1 \mathrm{H}, \mathrm{C}_{5}-\mathrm{H}\right), 12.96(\mathrm{~s}, 1 \mathrm{H}, \mathrm{N}-\mathrm{H}$, exch. $) ;{ }^{13} \mathrm{C} \mathrm{NMR}$ $\left(\right.$ DMSO$\left._{-}, 125 \mathrm{MHz}\right): 15.22(+), 115.62(-), 117.74(+), 123.03(+), 124.35(-), 125.50(-), 129.84(+)$, 134.66(+),136.29(-), $140.42(-), 144.20(-), 179.75(-), 183.77(-)$.

3-Methyl-6-chloro-1H-carbazole-1,4(9H)-dione [10]. m.p. $254^{\circ} \mathrm{C}$ (dec.); UV (MeOH) : 224, 259, 328, 395; IR $(\mathrm{KBr}): \mathrm{v}=3210,2978,1664,1645 \mathrm{~cm}^{-1} ;{ }^{1} \mathrm{H}$ NMR (DMSO-d 6 , 500MHz): $2.02\left(\mathrm{~s}, 3 \mathrm{H}, \mathrm{C}_{3}-\mathrm{CH}_{3}\right), 6.60(\mathrm{~s}, 1 \mathrm{H}$, $\left.\mathrm{C}_{2}-\mathrm{H}\right), 8.04\left(\mathrm{~s}, 1 \mathrm{H}, \mathrm{C}_{7}-\mathrm{H}\right), 8.22\left(\mathrm{~s}, 1 \mathrm{Hx} 2, \mathrm{C}_{5}-\mathrm{H} \& \mathrm{C}_{8}-\mathrm{H}\right), 12.92\left(\mathrm{~s}, 1 \mathrm{H}, \mathrm{N}-\mathrm{H}\right.$, exch.); ${ }^{13} \mathrm{C}$ NMR (DMSO-d ${ }_{6}$, $125 \mathrm{MHz}): 15.32(+), 114.50(-), 116.54(+), 123.13(+), 124.74(-), 129.31(+), 132.65(+), 135.78(-), 136.22$ $(-), 140.37(-), 146.79(-), 179.56(-), 182.45(-)$.

1.3 Procedure for $\mathrm{CAN}_{-} \mathrm{SiO}_{2}$ Mediated Oxidation of 15 to obtain quinones 9 and 10: A solution of cericammonium nitrate $(\mathrm{CAN}, 15 \mathrm{mM})$ in dry acetonitrile $(50 \mathrm{~mL})$ was mixed with silica gel $60-120$ mesh $(45$ g). On evaporation of solvent at room temperature a reddish free flow reagent was obtained. A solution of $\mathbf{1 5}$ $(2.5 \mathrm{mM})$ in dichloromethane $(35 \mathrm{~mL})$ was thoroughly mixed with the reagent followed by aerial evaporation of solvent. The reaction mixture obtained after overnight incubation at room temperature was then extracted with dichloromethane $(4 \times 50 \mathrm{~mL})$. The solvent was then removed to evaporation. The reddish brown solid thus obtained was chromatographed over silica gel $(30 \mathrm{~g})$ by eluting first with hexane and then with dichloromethane- hexane (3: 2). The eluent of dichloromethane- hexane fraction on evaporation afforded a red coloured solid. This was further purified through crystallization from dichloromethane- hexane mixture to furnish 9 and 10.

1.4 Bacterial cultures: Bacterial cultures of Escherichia coli (MTCC 42), Pseudomonas sp. (MTCC 6199), Bacillus subtilis (MTCC 121) and Staphylococcus aureus (MTCC 96) were obtained from the Microbial Type Culture Collection (MTCC), Institute of Microbial Technology (IMTECH), Chandigarh, India. Methicillin-resistant $S$. aureus (MRSA) was collected from the patient's sample of our institute.

1.5 Inoculum preparation: Inoculums were prepared by transferring three to five well-isolated colonies of identical morphology to $5 \mathrm{~mL}$ sterile nutrient broth from the respective nutrient agar plates. The broth cultures were then incubated for $24 \mathrm{~h}$ at $37^{\circ} \mathrm{C}$. Before the addition of inoculum the turbidity of the actively growing bacterial suspension was adjusted to match the turbidity standard of $0.5 \mathrm{McF}$ arland units.

1.6 Antibacterial activity assay: The antibacterial activity of compounds is studied as per standard agar well diffusion method (NCCLS 2000). Approximately $20 \mathrm{~mL}$ of molten Nutrient agar were poured in to sterile Petri dish and allowed to solidify. The bacterial suspension $\left(10^{6} \mathrm{CFU} / \mathrm{mL}\right)$ was inoculated uniformly onto the surface of agar plates and wells of uniform diameter were made on the solidifying agar media by the sterile borer. Test compounds were dissolved in DMSO and sterilized by filtration through $0.22 \mathrm{~mm}$ sterilizing Millipore express filter (Millex-GP, Bedford, OH, USA). Concentrations of the antimicrobial agents used for this assay were $2560 \mu \mathrm{g} / \mathrm{mL}, 1280 \mu \mathrm{g} / \mathrm{mL}$ and $640 \mu \mathrm{g} / \mathrm{mL} .100 \mu \mathrm{l}$ of particular dilutions were dispensed into the individually labeled wells. The plates were then kept in the refrigerator at $8-10{ }^{\circ} \mathrm{C}$ for proper diffusion of compounds into the media. After $1 \mathrm{~h}$ of cold incubation, the petri plates were transferred to incubator and maintained at $37^{\circ} \mathrm{C}$ for $24 \mathrm{~h}$. After overnight incubation, results were interpreted in terms of diameter (mm) of zone of inhibition surrounding the wells. Experiments were performed in triplicate for each test concentrations. The derivative that showed significant growth inhibition zone was further evaluated for their minimum inhibitory concentration (MIC) using standard broth dilution technique. The MIC is defined as the lowest concentration of a compound at which the visible growth of the organism is completely inhibited. Control 
experiments with DMSO and uninoculated media were run parallel to the test compounds under the same conditions.

\section{Results and Discussion}

The result of antimicrobial screening of our synthesized compounds, 6-chloro-2-methyl-1 $\mathrm{H}$-carbazole1,4(9H)-dione [9] and 6-chloro-3-methyl-1 $H$-carbazole-1,4(9H)-dione [10] by agar well diffusion method are shown in Table 1. From the data of the appraisal of zone of inhibition it is clear that compound $\mathbf{1 0}$ posses no antimicrobial activity against the tested organisms but compound 9 showed the promising activity against Staphylococcus aureus (MTCC 96) and Methicillin-resistant S. aureus (MRSA).

Table 1 Result of Antimicrobial activity assay by agar well diffusion method.

\begin{tabular}{|c|c|c|c|}
\hline Strain & Concentration & $\begin{array}{l}\text { Zone of inhibition }(\mathrm{mm}) \\
\text { compound } 9\end{array}$ & $\begin{array}{l}\text { Zone of inhibition (mm) for } \\
\text { compound } 10\end{array}$ \\
\hline Escherichia coli & A & NA & NA \\
\hline \multirow[t]{2}{*}{ (MTCC 42) } & B & NA & NA \\
\hline & $\mathrm{C}$ & NA & NA \\
\hline Staphylococcus aureus (MTCC & A & 19 & NA \\
\hline \multirow[t]{2}{*}{ 96) } & B & 17 & NA \\
\hline & $\mathrm{C}$ & 16 & NA \\
\hline Pseudomonas sp. & A & NA & NA \\
\hline \multirow[t]{2}{*}{ (MTCC 6199) } & B & NA & NA \\
\hline & $\mathrm{C}$ & NA & NA \\
\hline Bacillus subtilis & A & NA & NA \\
\hline \multirow[t]{2}{*}{ (MTCC 121) } & B & NA & NA \\
\hline & $\mathrm{C}$ & NA & NA \\
\hline Methicillin-resistant & A & 24 & NA \\
\hline \multirow[t]{2}{*}{ S. aureus (MRSA) } & B & 22 & NA \\
\hline & $\mathrm{C}$ & 21 & NA \\
\hline
\end{tabular}

Concentrations : $\mathrm{A}=2560 \mu \mathrm{g} / \mathrm{mL} ; \mathrm{B}=1280 \mu \mathrm{g} / \mathrm{mL} ; \mathrm{C}=640 \mu \mathrm{g} / \mathrm{mL}$. Zone of inhibition given in $\mathrm{mm}$ (diameter). NA : no inhibitory activity.

As the compound $\mathbf{9}$ showed clear zone of inhibition, it's minimum inhibitory concentrations against these two microorganisms were determined by standard broth dilution method. Experimental results of the broth dilution method which was employed for the determination of MIC value of the compound 9 against Staphylococcus aureus (MTCC 96) and Methicillin-resistant S. aureus (MRSA) are represented in Table 2 and Table 3 respectively.

Table 2 Result of the tube dilution method of Compound 9 against Staphylococcus aureus(MTCC 96)

\begin{tabular}{|c|c|c|c|c|}
\hline Compound & Tube no & $\begin{array}{l}\text { Antibiotic stock } \\
(\mu \mathrm{g} / \mathrm{mL})\end{array}$ & $\begin{array}{l}\text { Final concentration of } \\
\text { the tube }(\mu \mathrm{g} / \mathrm{mL})\end{array}$ & Growth observe \\
\hline \multirow{10}{*}{ Compound 9} & 0 & Nil & Nil & $+v e$ \\
\hline & 1 & Nil & Nil & $+\mathbf{v e}$ \\
\hline & 2 & 500 & 10 & $+\mathbf{v e}$ \\
\hline & 3 & 500 & 25 & $+\mathbf{v e}$ \\
\hline & 4 & 500 & 50 & $+\mathbf{v e}$ \\
\hline & 5 & 500 & 100 & -ve \\
\hline & 6 & 4000 & 160 & -ve \\
\hline & 7 & 4000 & 320 & -ve \\
\hline & 8 & 4000 & 480 & -ve \\
\hline & 9 & 4000 & 640 & -ve \\
\hline
\end{tabular}

Table 3 Result of the tube dilution method of Compound 9 against MRSA

\begin{tabular}{|c|c|c|c|c|}
\hline Compound & Tube no. & $\begin{array}{l}\text { Antibiotic stock } \\
(\mu \mathrm{g} / \mathrm{mL})\end{array}$ & $\begin{array}{l}\text { Final concentration of } \\
\text { the tube }(\mu \mathrm{g} / \mathrm{mL})\end{array}$ & Growth observe \\
\hline \multirow{10}{*}{ Compound 9} & 0 & Nil & Nil & $+v e$ \\
\hline & 1 & Nil & Nil & $+v e$ \\
\hline & 2 & 500 & 10 & $+\mathbf{e}$ \\
\hline & 3 & 500 & 25 & $+v e$ \\
\hline & 4 & 500 & 50 & -ve \\
\hline & 5 & 500 & 100 & -ve \\
\hline & 6 & 4000 & 160 & -ve \\
\hline & 7 & 4000 & 320 & -ve \\
\hline & 8 & 4000 & 480 & -ve \\
\hline & 9 & 4000 & 640 & -ve \\
\hline
\end{tabular}


It is clear from the experimental results that compound 9 has the MIC value of $100 \mu \mathrm{g} / \mathrm{mL}$ against $\mathrm{S}$. aureus (MTCC 96) and $50 \mu \mathrm{g} / \mathrm{mL}$ against methicillin-resistant $S$. aureus (MRSA). As compound 9 is highly sensitive against methicillin-resistant $\mathrm{S}$. aureus, this fact is very reassuring as the "super bug" MRSA has a significantly lower MIC value for this compound. So, our preliminary work gives an idea that 6-chloro-2methyl-1H-carbazole-1,4(9H)-dione [9] may be effectively useful in combating methicillin-resistant Staphylococcus aureus (MRSA), which has presently acquired resistance against many well-known antibiotics. The difference in activity between these two compounds having similar chemical skeleton, may be attributed due to the positioning of $-\mathrm{CH}_{3}$ group. We can also infer that compounds having the methyl group as substituent at C-2 position, exhibit anti-staphylococcal activity rather than their C-3 counterpart.

Though it has been reported that several 3-methyl carbazole alkaloids isolated from higher plants and their oxidative functional variants exhibited some biological activities, this experimental results finally strengthen our hypothesis that methyl group at C-2 is more effective as antibacterial agent than that at $\mathrm{C}-3$. This structure-activity relationship is in accordance with the carbazomycins which has methyl group at C-2 having pronounced biological activities.

\section{Conclusion}

The present research work fuel up the carbazole compounds with this new derivative 6-chloro-2methyl-1H-carbazole-1,4(9H)-dione [9], which showed excellent activity against methicillin resistant Staphylococcus aureus (MRSA). Uniqueness of this synthesized compound having methyl group at C-2 and chloro group at C-6 enriched the existing information of functional group assistance reactivity. Further research will be carried out using this synthetic tool to assist drug and development process which will provide future effective antimicrobial agent to fight against drug resistance bacteria.

\section{Acknowledgements}

We are thankful to Prof. Nandita Basu (Ghorai), Director, and Prof. Santanu Tripathi, Head of the Department of Clinical \& Experimental Pharmacology, School of Tropical Medicine, Kolkata, for their interest in the work. The authors would like to acknowledge Dr. Sanjoy Ghosh, Department of Biochemistry, University of Calcutta for helpful suggestions. We are also thankful to The West Bengal University of Health Sciences to allow us for this work.

\section{References}

[1] D. P. Chakraborty, B. K. Barman and P. K.Bose, Sci. Cult., vol. 30, pp. 445, 1964.

[2] D. P. Chakraborty, B. K. Barman and P. K.Bose, "On the constitution of murrayanine, a carbazole derivative isolated from Murraya koenigii Spreng," Tetrahedron, vol. 21, pp. 681-685, 1965.

[3] K. C. Das, D. P. Chakraborty and P. K. Bose, "Antifungal activity of some constituents of Murraya koenigii Spreng," Experientia, vol. 21, pp. 340, 1965.

[4] H-J. Knölker, and K. R. Reddy, "Isolation and Synthesis of Biologically Active Carbazole Alkaloids," Chem. Rev., vol. 102, pp. 4303-4427, 2002.

[5] H-J. Knölker, "Transition Metal Complexes in Organic Synthesis, Part 70\&\#. Synthesis of Biologically Active Carbazole Alkaloids Using Organometallic Chemistry,” Curr. Org. Synth., vol.1, pp. 309-331, 2004.

[6] I. Bauer, and H-J. Knölker, "Synthesis of Pyrrole and Carbazole Alkaloids," Top. Curr. Chem., vol. 309, pp. $203-253,2012$.

[7] A. W. Schmidt, K. R. Reddy, and H-J. Knölker, "Occurrence, Biogenesis, and Synthesis of Biologically Active Carbazole Alkaloids," Chem. Rev., vol. 112, pp. 3193-3328, 2012

[8] K. Sakano, K. Ishimaru and S. Nakamura, "New antibiotics, Carbazomycins A and B I. Fermentation, Extraction, Purification and physico-chemical and biological properties," J. Antibiot., vol. 33, pp. 683-689, 1980.

[9] K. Sakano and S. Nakamura, "New antibiotics Carbazomycins A and B. II. Structural elucidation,” J. Antibiot., vol. 33, pp. 961 966, 1980.

[10] M. Kaneda, K. Sakano, S. Nakamura, Y. Kushi and Y. Iitaka, “The structure of Carbazomycin B,” Heterocycles, vol. 15, pp. 993998. 1981

[11] K. Yamasaki, M. Kaneda, K. Watanabe, Y. Ueki, K. Ishimaru, S. Nakamura, R. Nomi, N. Yoshida and T. Nakajima, "New antibiotics, Carbazomycins A and B III. Taxonomy and Biosynthesis," J. Antibiot., vol. 36, pp. 552-558, 1983.

[12] S. Kondo, M. Katayama and S. Marumo, "Carbazomycinal and 6-methoxycarbazomycinal as Aerial mycelium formation-inhibitory substances of Streptoverticillium species,” J. Antibiot., vol. 39, pp.727-730, 1986.

[13] T. Naid, T. Kitahara, M. Kaneda and S. Nakamura, "Carbazomycins C, D, E and F, minor components of the Carbazomycin complex," J. Antibiot., vol. 40, pp. 157-164, 1987.

[14] M. Kaneda, T. Naid, T. Kitahara, S. Nakamura, T. Hirata and T. Suga, "Carbazomycins G and H, Novel Carbazomycin congeners containing a quinol moiety,” J. Antibiot., vol. 41, pp. 602-608, 1988.

[15] H-J. Knölker, M. Bauermeister, D. Bläser, R. Boese, and J-B. Pannek, "Highly Selective Oxidations of Fe(CO) ${ }_{3}-\mathrm{Cyclohexadiene}$ Complexes: Synthesis of 4b,8a-Dihydrocarbazol-3-ones and the First Total Synthesis of Carbazomycin A, Angew. Chem. Int. Ed. Engl., vol. 28, pp. 223-225, 1989.

[16] H-J. Knölker, and M. Bauermeister, "The total synthesis of the carbazole antibiotic carbazomycin B and an improved route to carbazomycin A,” J. Chem. Soc. Chem. Commun., pp. 1468-1470, 1989.

[17] H-J. Knölker, and M. Bauermeister, "Transition Metal-Diene Complexes in Organic Synthesis. Part 15. Iron-mediated total synthesis of carbazomycin A and B," Helv. Chim. Acta., vol. 76, pp. 2500-2514, 1993.

[18] H - J. Knölker, and G. Schlechtingen, "First total synthesis of carbazomycin C and D," J. Chem. Soc., Perkin Trans., vol. 1, pp. 349 $-350,1997$. 
[19] D. J. Hook, J. J. Yacobucci, S. O'Connor, M. Lee, E. Kerns, B. Krishnan, J. Matson and G. Hesler, "Identification of the Inhibitory Activity of Carbazomycins B and C against 5-lipoxygenase, A new activity for these compounds," J. Antibiot., vol. 43, pp. 1347-1348, 1990 .

[20] Chakraborty B, Chakraborty S, Saha C, “Antibacterial activity of Murrayaquinone A and 6-methoxy-3,7-dimethyl-2,3-dihydro-1Hcarbazole-1,4(9H)-dione,” Int J Micro, vol. 2014, pp. 1-8, 2014.

[21] F. F. Zhang, L. L. Gan, and C. H. Zhou, "Synthesis, antibacterial and antifungal activities of some carbazole derivatives," Bioorg. Med. Chem. Lett., vol. 20, pp. 1881-1884, 2010.

[22] C. Asche, W. Frank, A. Antje and U. Kucklaender, "Synthesis, antitumour activity and structure-activity relationships of 5Hbenzo[b]carbazoles," Bioorg. Med. Chem., vol. 13, pp. 819-837, 2005.

[23] R. B. Bedford and M. Betham, "N-H carbazole synthesis from 2-chloroanilines via consecutive amination and C-H activation," J. Org. Chem., vol. 71, pp. $9403-9410,2006$.

[24] R. B. Bedford, M. Betham, J. P. H. Charmant and A. L. Weeks, "Intramolecular direct arylation in the synthesis of fluorinated carbazoles," Tetrahedron, vol. 64, pp. 6038-6050, 2008.

[25] A. Bombrun and G. Casi, "N-Alkylation of 1H-indoles and 9H-carbazoles with alcohols," Tetrahedron Lett., vol. 43, pp. 2187 $2190,2002$.

[26] A. Bombrun, P. Gerber, G. Casi, O. Terradillos, B. Anitosson and A. Halazy, 3,6-dibromocarbazole piperazine derivatives of 2propanol as first inhibitors of cytochrome C release via bax channel modulation", J. Med. Chem., vol. 46, pp. 4365-4368, 2003.

[27] K. M. Meragelman, T. C. McKef and M.P. Boyd, "Siamenol, a new carbazole alkaloid from murraya siamensis", J. Nat. Prod., vol. 63, pp. 427-428, 2000.

[28] T. A. Choi, R. Czerwonka, W. Fröhner, M. P. Krahil, K. R. Reddy, S.G. Franzblau and H-J. Knölker, "Synthesis and activity of carbazole derivatives against mycobacterium tuberculosis", Chem. Med. Chem., vol.1, pp. 812-815, 2006.

[29] T. A. Choi, R. Czerwonka, R. Forke, A. Jager, J. Knöll, M. P. Krahil, T. Krause, K. R. Reddy, S.G. Franzblau and H-J. Knölker, "Transition metals in organic Synthesis - Part 83. Synthesis and pharmacological potential of carbazoles", Med. Chem. Res., vol. 17, pp. 374-385, 2008.

[30] T. Nagappan, P. Ramasamy, M. Wahid, T. C. Segaran and C. S. Vairappan, "Biological Activity of Carbazole Alkaloids and Essential Oil of Murraya koenigii Against Antibiotic Resistant Microbes and Cancer Cell Lines,” Molecules, vol. 16, pp. 9651 9664, 2011.

[31] B. K. Chowdhury, and D. P. Chakraborty, "Mukoeic acid, the first carbazole carboxylic acid from a plant Source," Phytochemistry, vol. 10, pp. 1967-1970, 1971

[32] H.-J. Knolker, and K. R. Reddy, "Isolation and synthesis of biologically active arbazole alkaloids," Chemical Reviews, vol. 102, pp. 4303-4427, 2002.

[33] C. Ainsworth, "Indazole," Org. Synth. Coll, vol. 4, pp. 536-539, 1963.

[34] C. Saha, A. Chakraborty and B. K. Chowdhury, "A new synthesis of 4- deoxycarbazomycin B and its antimicrobial properties," Indian J. Chem., vol. 35B, pp. 677-680, 1996

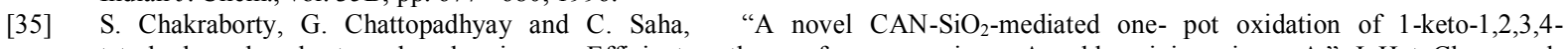
tetrahydrocarbazoles to carbazoloquinones: Efficient syntheses of murrayaquinone A and koeniginequinone A,” J. Het. Chem., vol. 48, pp. 331-338, 2010. 